K. Ingram ${ }^{1}$, orcid.org/0000-0001-9136-1896, V. Nitsenko ${ }^{2}$, orcid.org/0000-0002-2185-0341
1 - Vilniaus Kolegija, University of Applied Sciences, Vilnius, the Republic of Lithuania, e-mail: k.ingram@vvf.viko.lt 2 - SCIRE Foundation, Warsaw, the Republic of Poland

\title{
COMPARATIVE ANALYSIS OF PUBLIC MANAGEMENT MODELS
}

Purpose. Comparative assessment on the relevance of paradigms that lead to the development of new public administration models.

Methodology. A comparative analysis was conducted in the research in order to provide a comprehensive understanding, from occupational and academic viewpoints, on the existing public administration models, which are traditional public administration, new public management and new public governance, spatial features which contribute to new paradigmatic 'exemplars' and 'viewpoints'.

Findings. There are some important aspects in the understanding of paradigms in public administration models. To that extent the overall framework of public administration models are paradigms that constantly shift when a crisis occurs. This demonstrates that the new developed public administration models will not always fit in one paradigm, and can exist in a hybrid state where various characteristics of other paradigms overlap the other. Identifying these characteristics aids in determining the applicability of current models to regulating governance and management of public sector entities and functions as well as its designation.

Originality. Previous research indicates that numerous attempts in understanding and developing a systematic approach to the order of public administration have been made. To date, the development of public administration as a discipline is perceived as a succession of overlapping paradigms. Notwithstanding this, public administration still remains the single most important aspect of bureaucracies in the world. With the government deciding on all aspects of civil society in capitalist, socialist and democratic states the objectives of public administration are termed to be in a continuous state of paradigm shift. Paradigms provide solutions and determine whether areas of a particular phenomenon are problematic and many public administrative practitioners have often adopted the paradigmatic assumptions that politicians, officials, and citizens are motivated by self-interest, and will perceive the development in public administration in this light.

Practical value. The work provides an interpretation on the functions and prospects of public administration as a discipline that lead to the development and transition from traditional public administration (TPA) to new public management (NPM), then new public governance (NPG) and further on to other post-new public management models.

Keywords: public administration, traditional public administration, new public management, new public governance, paradigm

Introduction. The term public administration consists of a complex set of interrelated theories, derived from many different academic fields, includes a variation of agencies, and is closely related to a number of professions $[1,2]$. As the main arm of implementing government policy, public administration is also an academic discipline that studies this implementation by the government, prepares civil servants for employment as public servants, a precondition for a transparent and effective public governance by assessing the government's ability to provide requisite public service and fostering a nation's competitiveness and growth and is the key foundation of a well-functioning state $[1,3]$. In addition to monitoring and implementing government programmes, and the behaviour of non-elected officials and their conduct, public administration also covers the judicial practice and interpretation of laws, their enactment and the governing and administration of programmes implemented based on those laws. This includes legislation, immigration, foreign and domestic affairs, taxation, security and national defence programmes.

Literature review. In regards to the study on public administration as an academic discipline, there is large debate among scholars over whether it is a subpart of administrative science or political science $[4,5]$. In reality the study on public administration should encompass not only the fundamental view of advancing management and policies to facilitate government functions but also the study on government decision making and policies, and how political decisions are converted into reality that the public can see [6, 7]. Therefore, from an interdisciplinary retrospect public administration is primarily drawn from three main study fields - law, management and political science, and secondarily from subjects within the social and natural sciences field. Moreover, when regarded as an academic discipline the content will include a plethora of theory and concepts with economics, management and administration principles from a cross-governmental context. During the 1880s when the $28^{\text {th }}$ president of the United States of America,

(C) Ingram K., Nitsenko V., 2021
Thomas Woodrow Wilson, enacted the American civil service reform thus changing public administration as a service into an academic discipline, yet it was not until the middle of the twentieth century and spreading of Max Weber's theory of bureaucracy that the interest of public administration theory arose. Since then the public administration as a discipline has been broadened to include human resources, organizational theory, policy analysis and statistics, budgeting, and ethics.

A simple definition for public administration would not be sufficient when considering the scope to include the activities of government that are directed towards the interest of the public, and executed in a collective manner within a political context $[8,9]$. However, in ascribing a definition for the term from a governmental context, a collectivist approach would have to be undertaken as the legal framework of public administration infers that its foundations are bound by instruments of law, and constitutes regulations, statutes and codes; the managerial context definition would be the executive nature in which the public's will is carried out and translated into action according to those persons in charge of public bureaucracy [10, 11].

The occupational stance would cover all aspects of the managerial framework for various occupational fields such as social welfare, health and engineering that are transformed by public administrators into the work of government $[1,2]$. It also involves the grouping of public bureaus in varying ministerial departments of government, at the local and state levels and supervising its civil servants and public officials, and the formulation of policies enforced by political actors. Notably, the administrative aspect will be the connecting factor between the leadership and organisation phase and for all social activities, the simple yet essential part of its continuance. Moreover, administration connotes to the private or public dimension and its difference is important $[12,13]$. As a social science public administration as an academic discipline has contributed strongly to this field due in part to the complexity and the multidisciplinary nature of it. Thus when taken from these definitions, public administration is inferred as an academic discipline and an occupation [3, 14]. 
We grouped and analysed our research in the following directions:

1. Characteristics of Public Administration Models:

- Traditional Public Administration. This has been extensively researched by Osbourne S. P. (2006); Shafritz J. M. and Hyde A. C. (2007); Stout M. (2010); Fox C. J. and Miller H. T. (1995); Rozin V. [4]; Ryu S. [5]; Latysheva O., et al. [11], and others;

- New Public Management. The key aspects have been disclosed by Farazmand A. (2006); O'Flynn J. (2007); Page S. (2007); McCandless S. A. and Guy M. E. (2013); Baharun R., et al. [6]; El-Ghalayini Y. [10]; Chand A., and Naidu S. [12], etc.;

- New Public Governance. This concept has been researched by Pfiffner J. P. (2004); Dunleavy P. and Margetts H. (2006); Osbourne S. P. (2006); Raipa, A. (2011); Ingrams A., et al. [7]; Kalinichenko A., et al. [8], etc.

2. Public Administration as paradigms as referenced to Kuhn's research (1970); Jackson N., and Carter P. (1991); Kettl D.F. (1993); Collier D. (1993); Onwuegbuzie A.J., Leech N. L., and Collins K. M. (2012); Katsamunska P. (2012); Gow J. I., and Dufour C. (2001); Syomych M. [9], and others.

The purpose of the article is to comparatively analyse public administration models. The aim is to gain insights and then to explore and discuss each model's structural development from theoretical research on the paradigmatic "exemplars" and "world views".

Methods. A comparative analysis was conducted in order to provide a comprehensive understanding, from occupational and academic viewpoints, on the existing public administration models, which are traditional public administration, new public management and new public governance, spatial features that contribute to new paradigmatic "exemplars" and "viewpoints".

Results. Characteristics of the Public Administration Models. Traditional Public Administration. As previously mentioned, traditional public administration is associated with Max Weber (contemporary model), Frederick Taylor and Woodrow Wilson (classical model), the latter is known as 'The Father of Public Administration' in the United States ever since his famous book "The Study of Administration" in 1887. The classical model purported by Wilson and initially developed in the United States is considered the best approach for organizing public sector work. The classical model in practice became predominant in western societies during the nineteenth and early twentieth century. The main difference when compared to Europe is the transfer of effective management theories and practices between large private and public organizations. The main argument of Wilson's model is that a bureaucracy should operate like a business and some of the key characteristics are promotions in the public sector organizations should be based on merit, public sector should be non-political, professionalization in public service should be maintained and it must be pragmatic.

1. From his work the "Principles and Methods of Scientific Management", Frederick W. Taylor in 1911 effectively coined the term "Scientific Theory" as an approach to management which was then further used to implement ideas that would increase the efficiency of public administration institutions in the United States. According to Taylor, implementing systematic control, hierarchical organizational systems and standardizing work processes, are more suitable for public sector governance. On the other hand, Max Weber's model presents a more contemporary approach to public administration theory because it takes into account the fact that a society's culture can be integrated into a theory, a term called interpretive sociology. Interpretive sociology is defined as "the understanding of ideas and practices from within a particular intellectual and cultural context and from those contexts are grounded in a meaningful social and historical framework". The main characteristic of Weber's model is its interpretive sociology approach, which employs a useful tool "value judgements" that act as a guide for structuring observations, analyse and evaluate or interpret the findings [15]. The development of Weber's method is attribut- ed to this tool as well. Weber's methods are termed as the "ideal-type" and utilize the theory building method technique, which demonstrates the importance of values in sense making (also known as meaningful social science), as opposed to the assertion of theory relevance. Weber's interpretive sociology uses the functional analysis approach, which starts from the whole then proceeds to the parts, and then back from the parts to the whole again and his "ideal-type" methodology is useful for the study on social structure and social action. Weber contends that all social action has a subjective meaning at the individual level and that structural forms are the construction of social action. This combination is particularly relevant and useful to public administration because the manner in which administrative action and the control of social structures interconnects will require a method that considers both. While Weber's ideal-type model enables the interpretation of alternative meanings or motivations held by social actors on the one hand, on the one hand it constitutes and enables an analysis of the consequential role of social structures to social actors. From this stance, the "ideal-type" is a useful tool in aiding sociologists to interpret certain meanings in public administration theory particularly the administrative role and for critiquing the institutions of governance.

According to Osbourne, the key elements or characteristics of traditional public administration can be defined as:

1. Rule of law is dominant.

2. More focused on administering guidelines and obeying the rules set.

3. Bureaucracy plays a key role in public sector implementation and public-policy.

4. Great division between politics and administration in public organizations.

5. Incremental budgeting.

6. More control on the professional in the service delivery system.

As evidenced by Osbourne, the traditional public administration entered a terminal decline, after the early years of the public sector in the late nineteenth century, and has led to the rise of the new public management model.

New Public Management. The new public management model represents new developments that were made to public administration theory, and is a new approach to governance of public service organizations used in government and the control of public service institutions and agencies at sub-national and national levels. From that stance it is argued to be a further extension of public administration theory. The term itself was first introduced by academics from the United Kingdom and Australia to describe the techniques developed during the 1980s as part of an effort to make public services more 'business-like' and to improve its efficiency by using private sector management models and free market principles into the public sector [16]. Hence, the new public management model could potentially be implemented into the private sector as well in effect from a radical perspective. For the United Kingdom the new public management model worked very well, and became the prominent theory that inspired health care reforms for that country as it coincided well at a period when growing expenditures used in health care, due to the introduction of technology as well as the aging population, need a solution that works best for that state and its citizens. At that time government ideology as well as the huge significant difference in budgetary process between the private and public sectors provided a conflict of interest. However, the UK's National Health Service was able to overcome those barriers and using the new public management model successfully created an internal market of separate care providers and hospitals which in turn freed the State from performing two roles, being the funder and service provider of health care, leading to just the primary role of a funder. From this, one can see how the new public management approach of making public services more "businesslike" and "customer service" oriented will enable the State to 
focus centrally on its citizens, who are the recipients of those services from the public sector [17].

With the advent of the new public management model, came the private sector-style corporate governance of a Board of Directors system was used as a strategic guideline for public organizations and many reforms to the public sector policies and programs as it is seen as a more efficient means of achieving the same outcomes. It is interesting to note that while new public management is used in many countries around the world, it is mainly associated with industrialized Organisation for Economic Co-operation and Development (OECD) countries including the United States of America. Several other characteristics of new public management are: citizens are viewed as "clients or customers" and public servants as managers; there is a parallel alignment to the relationship between public service managers and their political superiors; there is an incentive-based motivation system for public sector managers such as pay-for-performance, and clear benchmarks are often set, which are assessed using performance evaluation systems; there is relatively greater discretion and freedom for public sector managers in how they achieve goals set for them; lastly the model contrasts significantly to the traditional public administration model, where the former is largely guided by legislation, administrative procedures and regulations for policy-making, institutional decision-making and public service delivery. Lastly, the new public management model fosters innovation through the application of the entrepreneurial spirit to public service and grants a wide range of choices for customers as well [12]. On the other hand, its implementation into the public sector has failed to address many political issues. Scholars have contended that the new public management model advocates that public administration developed its roots from capitalism, only serves the interests of corporate elites, and has contributed to the degradation of the government ability to address the public's needs; further on it is posited that new public management serves as the vehicle elevating "apolitical governance" of free trade and other supranational organization that fully embraced economic rationalism and new managerialism [7].

New Public Governance. "Governance", and "public governance", two terms that are used interchangeably in public administration literature when one refers to new public governance theory or new public management theory. Both models share many common features; however, they are not the same as new public governance covers many approaches to governance of the public sector $[15,16]$. Osbourne suggests that a definition for new public governance should capture "self-organizing inter-organizational networks" aspect of governance that functions both with and without government to provide public services. The key yet unique feature of new public governance is that its development was not integrally derived from other models and hereby it is thus defined as an alternate discourse. While the main idea behind the new public administration model was aligning academic public administration with the radical free thought prevalent in the United States, and for new public management, which was more or less inclined to reforms made to managerial side of public administration and improving the quality and efficiency of public services, new public governance is modernization of the government and public sector and is collectively termed as post-NPM or digital-era governance. This model built on institutional and network theory and represents a complete synthesis of Weberian bureaucracy and the new public management of the 1980s which is purely focused on cooperation, coordination, uniting of disjointed services in the public sector in order to increase more autonomy, simplification and flexibility within the context of digital-era governance. Overall, the main idea is to implement a holistic approach to governance which is centred on establishing more collaborative relationships between public and private sector entities and digitization are key important features. According to Dunleavy and Margetts and Osbourne, the main elements, characteristic of new public governance model, are:
1. Reintegration of separated government services or interorganizational governance.

2. Need-based holism: that is based on new relationship with citizens, more simplification and flexibility in services.

3. Digitization: maximum use of modern information and communication technology.

4. Emphasis on service processes and outcomes.

5. Neo-corporatist.

However, Raipa contends that the strategic nature of new public governance is the one that further encompasses elements such as quality characteristics of all resources coordination, modern state financial-economic possibilities, inter-sectoral intersection of improved planning, improved competency in the organizational behaviour of public servants, managers and elected officials $[6,7]$. These elements are collectively linked into scientific-systematic determinants, where the development of the model is becoming one of the central spheres of interaction, integration and collisions as the changes in public policy and administration are influenced by the globalized environment.

Public Administration Paradigms. The paradigmatic development of public administration discipline is mostly attributed to the fact that public administration is everyone's business. So in retrospect it is the way the discipline has conceptualised over time in respect to the public, the electorate, to the elected officials. Kuhn states that paradigms as a theory in the social sciences field are termed as pre-paradigmatic sciences and it is the period in which a particular discipline lacks a common set of exemplary theories and practices and mainly consists of a collection of ad hoc propositions [3,9]. In reference to paradigms in public administration, the three levels are outlined in Table.

As a result, for the latter half of the previous century each paradigm has differentiated itself through the unique set of theories, legal, political, and professional contexts developed. The proto-paradigm will be the relationship between public administration and politics, based on formal logic with four paradigms identified and the fifth one developed conceptually. For each paradigm in public administration, the relevance of a phenomenon is highlighted, a balance is established between the pros

Table

Kuhn's Theory of Paradigms

\begin{tabular}{|l|l|c|}
\hline \multicolumn{1}{|c|}{ Paradigm } & \multicolumn{1}{|c|}{ Features } & Level \\
\hline Eetaphysical/ & $\begin{array}{l}\text { Paradigm is equated with a new set of } \\
\text { beliefs or a successful metaphysical } \\
\text { speculation (new standards or } \\
\text { perspectives); purely a metaphysical } \\
\text { concept or belief rather than a } \\
\text { scientific one }\end{array}$ & First \\
\hline Sociological & $\begin{array}{l}\text { Sociological paradigms that are } \\
\text { broader than the scope of the scientific } \\
\text { theory; Usually includes the beliefs and } \\
\text { value systems and generalizations } \\
\text { derived or universally accepted } \\
\text { scientific achievements }\end{array}$ & Second \\
\hline Exemplars & $\begin{array}{l}\text { These are concrete problem-solutions } \\
\text { (i.e. tools or analogies) and are the } \\
\text { most central meaning of paradigm. } \\
\text { Key feature of exemplars is that they } \\
\text { question the sociological and } \\
\text { metaphysical paradigms when } \\
\text { anomalies are detected; Exemplars are } \\
\text { cited as the 'backbone of normal } \\
\text { science', provide tangible proof of the } \\
\text { paradigm's theoretical perspective } \\
\text { through the organization of observable } \\
\text { facts, and permit the transmission of } \\
\text { the theoretical foundations developed } \\
\text { from classical problem-solution } \\
\text { mechanisms }\end{array}$ & Third \\
\hline
\end{tabular}


and cons in the changes planned for public bureaucracies, problems are identified as well as solutions which are appropriate. In Table, paradigms in public administration can be applied according to the relevant levels of aggregation including the macro-level (politics and administration), the meso-level (the organisational parts of public administration), and the microlevel (the bureaucrat), where at each level the dominant paradigm will govern along with its accompanying theories [3, 9].

This is done in order to critically examine and analyse traditional public administration, new public management and new public governance in order to understand, from an occupational and an academic standpoint, how decisions in government are made and how functions and administration of government projects and programmes are carried out in order to support these decisions. A literature review of secondary scientific articles and monographs was essential as it represents the first and most important step in qualitative research studies. The theoretical analysis helps to gain more understanding about the features of each model and their role in the public administration framework. Taking into consideration each models' characteristics, it became necessary to comparatively analyse them as paradigms using Thomas Kuhn's "cycle" to assess and discuss the structural development of each in public administration, within three contexts as an academic discipline, an administrative science and political science. Comparative analysis is a useful type of research methodology as Collier defines comparison as a fundamental tool of analysis that sharpens our power of description and plays a key role in concept-formation by bringing into focus suggestive similarities and contrasts among cases.

Historically, traditional public administration or the classical model has always been practised in parallel with the government. Since the onset of the twentieth century the classical model, derived from Taylor, Weber and Wilson, Weber's concept of bureaucracy has evolved to become the leading principle for the traditional model of public administration, and synonymous with "rule of law". The key characteristic of this "paradigm" was that it focused more towards bureaucracy, rules, policy making and implementation, resulting in a 'politics-based administration' division within public organizations. During the late nineteenth century the paradigm was at a high point especially in the United Kingdom during the era of the welfare state. At that time, it was presumed that the state would confidently meet all the social and economic needs of citizens from the cradle to grave and it was a symbol of the brave new world. Predictably, this was a tunnel-vision approach, doomed for failure at the very beginning, criticized incessantly by academics and the political elite. However, when that model changed due to its overarching theoretical and practical obsolescence in the mid-1980s, the classical model began to develop a more market-based tendency, with the role of government in society and its relationship to citizenry significantly changed. Even more so, the introduction of modern managerial approach and the adoption of the new public management system meant the emergence of a new paradigm as the wave of reforms from Anglo-American played a key role in the development of private sector reforms towards modernization of the government. Another distinct model of reform, adopted by many European countries was established to govern the state in a stable and more predictable way rather than the static previous one. Though this model was met with significant resistance due to the accompanying challenges, a selective approach was adopted with limited usage of its elements and instruments.

New public management, the main rival of public administration during the mid-1980s, was a different approach to the operations of public service organizations used by the government. With new public management, the management of public service institutions and agencies was executed in a more business-like approach. Efficiency improved as the model utilized private sector management methods with a keen focus on customer service. The reforms implemented to develop new public management are derived on the centrality of citizens, who are the main recipients of public services customers to the public sector. Moreover, decentralization of various service delivery models such as e-government has resulted in reduced costs, faster service to the public, auditing and establishing of benchmarks and performance evaluations. Another key feature of reforms in new public governance is that it adopted a quasi-market style to deliver public services through private sector companies. Indeed, there are many aspects of this model that are not attuned to traditional public administration; however, a distinction in regards to its compatibility to the bureaucratic administration extends beyond the modernist detailed differentiations between the state and administration. The decentralization of services, although one of the more appealing and desirable traits of the model, is very similar to a federalist state. Another drawback of new public management is that it is more suited for fully developed governments and is not a prescription for non-industrialized developing economies as 'improvement' is marginal. New public management is often termed as the new paradigm that has replaced the classic Weberian paradigm of public administration (also termed as a bureaucratic paradigm). However, Kuhn's notion being used, the main question is the validity of this model as a paradigm. Do the new ideas copied from business, management and economics constitute a new thing and hence to what degree is the difference between new public management and public administration, and further, to what extent has it really challenged the latter in what a total replacement has resulted?

According to scholars, new public administration is classified as a new paradigm only from the epistemological approach but it is not a superior theory or a unified comprehensible perspective of exemplars. This is evidenced where the main characteristics of nature of public administration as a paradigm was more aligned to Weber's bureaucratic model. For a paradigm to occur there must be a crisis state. The Westminster model, where political authority resided in ministers and the cabinet with an impartial public service advising the elected officials, was very useful for governments such as Canada or Australia, which adopted this model as the results were very positive and very similar to Weber's model. However, with the Canadian version of the Westminster model being used, the crisis that resulted in the emergence of new public management was caused by conceptual and practical problems (also known as exemplars), an accumulation of anomalies, intellectual challenges, and the new market-based ideologies adopted. When new public management was introduced in the 1960s, as a paradigm, it ensured neutrality of the public service, restored faith in the Public Service Commission and contributed to more bureaucracy in government procedures and processes through the implementation of collective agreements. This evidence stipulates that the evolution of the state had created conditions for challenging the traditional model, which in reality was not undergoing an intellectual crisis, rather was generating conditions that were difficult to understand using its concepts. According to Gow and Dufour, the new public management model was derived from a practical sphere rather from an intolerable intellectual crisis; public administration underwent a crisis of credibility and was no longer applicable in the contemporary world of public and private management.

Furthermore, as a new paradigm, new public administration, did replace the old model of new public administration due to the fact that it offered a vigorous new approach to governance without forfeiting the best of the old values. On the intellectual side, although the classic model adopts business management theories such as those by Taylor, Fayol, Wilson and others, in an overall manner, public administration and new public administration usually cover the same thing but from a different approach. Both models are very comprehensive and share common core principles from other contributing academic fields such as work psychology organization theory, financial management, economics and sociology and so on. Public administration, however, differs in the point that is based more on law, while the 
new public management model leans heavily towards the economics and business administration academic disciplines. The main commonalities of both models are that they are heavily criticized as being too short in theory and fundamental research; thus, both models do not possess a comprehensive view of the whole field. Scholars also argue that not much accumulation of knowledge has resulted and due to this a lack of combined theory have caused partial adherence to the paradigm.

Despite this, most governments tend to adopt a hybrid system which encompasses both models. Therefore, from that perspective the development of new public management from the classic model, is classified as an evolution rather than a revolution and cannot be viewed as a paradigm. However, for new public management, private sector values prevail and hence were adopted by public sector organizations [3, 17]. In addition, "micro-management", lack of work motivation, the absence of an evaluation system for measuring achievement in a useful and positive way have led to poor results in the classic model; hence, the crisis of state occurred. Connoted to the semblance of an "empty shell" and brutally undermined by public policy and public management, it is contended that the classic model was "nourished" more or less by the new public management paradigm, where greater emphasis is placed on promoting the lesser known aspects of public administration liker example practitioner knowledge. Finally, the main opposition between the two models is that while both their "paradigms" exist at the metaphysical level, at the rhetorical level, NPM is presented as the superior model; however, it is stated that if they are rival paradigms, each has the capability to 'learn from the other without losing their uniqueness'.

From an intrinsic view, the new public governance paradigm combines the strengths of public administration and new public management into a coherent conceptual framework that integrates theory and research to support public administration practices [9, 13]. Moreover, Osbourne and Runya, et al. [2] contend and have evidenced that new public governance as a new paradigm of public administration, not only facilitated a new research framework for theoretical study, but brought a new style of practices in public administration which incorporates the micro-, macro- and meta-level of elaboration that resulted in the development of new public governance paradigm itself. The development of the contemporary society and the western public sector also contributed to the transition of the paradigm in the field of public administration from "the new public management" to "the new public governance" according to Runya, et al. [2].

\section{Conclusions.}

1. The theoretical analysis of literature defines public administration in practice as activities that are undertaken by the government at the state and local levels, where the executive and operative branch of government formulates and enforces public policies which are then enacted by legislation. At the occupational level, public administration prepares citizens for employment as either civil servants, managers, administrators or elected officials serving the interest of the people. At the institutional level, public administration involves the development of public bureaus and agencies in varying ministerial departments of government, at the local and state levels, which supervise civil servants and public officials, and the formulation of policies enforced by political actors. At the academic level, public administration has contributed strongly to this field due in part to the complexity and the multidisciplinary nature of it, where it is further split into governance (legislation and law), management and a science and therefore is embraced as an occupation and an academic discipline.

2. The characteristics of public administration models are intrinsically unique in the fact that the shortcomings of one model have led to the development of a new model for the last three centuries. In summary, traditional public administration is mainly aligned with Wilson and Weber and is built upon Taylor's scientific approach to management; new public management is featured to be more customer-centric and adopts a business-like approach to public governance, principles 'borrowed from the private sector; new public governance characteristically operates well in plural and pluralist society, adopts inter-organizational (digital-era) governance, where trust and relational contracts are enforced.

3 . From the comparative analysis, the three main models of public administration are intrinsically identified as three key paradigms, namely regime and procedure (traditional public administration), efficiency (new public management) and democracy and efficiency (new public governance). In reference to the strength of each model this is best highlighted during the era it was developed while the main weakness of each, except for new public governance which is the current model, would be the moment its principles became obsolete due to the changing needs of government and the public sector.

\section{References}

. Aderibigbe, A. M., \& Oluwafemi, J. (2014). Towards A Theoretical Definition of Public Administration. IOSR Journal of Business and Management (IOSR-JBM), 16(3), 65-70. https://doi. org $/ 10.9790 / 487 X-16356570$.

2. Runya, X., Sun, Q., \& Si, W. (2015). The Third Wave of Public Administration: The New Public Governance. Canadian Social Science, 11(7), 11-21. https://doi.org/10.3968/7354.

3. Snellen, I. M. (2014). Foundations of Public Administration: An Essay in Tis Paradigms. The Hague: Eleven International Publishing. Retrieved from https://www.bookdepository.com/Foundations-PublicAdministration-I-Th-M-Snellen/9789462361089.

4. Rozin, V. (2021). From Engineering and Technological Process to Post-Cultural Technology. Future Human Image, 15, 99-109. https:// doi.org/10.29202/fhi/15/9.

5. Ryu, S. (2016). Modeling Public Management: Current and Future Research. Public Organization Review, 16, 77-94. https://doi. org/10.1007/s11115-014-0297-4.

6. Baharun, R., Jing Mi, T., Streimikiene, D., Mardani, A., Shakeel, J., \& Nitsenko, V. (2019). Innovation in healthcare performance among private brand's healthcare services in small and medium-sized enterprises (SMEs). Acta Polytechnica Hungarica, 16(5), 151-172. https://doi.org/10.12700/APH.16.5.2019.5.9.

7. Ingrams, A., Piotrowski, S., \& Berliner, D. (2020). Learning from Our Mistakes: Public Management Reform and the Hope of Open Government. Perspectives on Public Management and Governance, 3(4), 257-272. https://doi.org/10.1093/ppmgov/gvaa001.

8. Kalinichenko, A., Havrysh, V., \& Nitsenko, V. (2019). Alternative Vehicle Fuel Management: Impact on Energy Security Indicators. In Krakowiak-Bal, A., \& Vaverkova M. (Eds.) (2019). Infrastructure and Environment, (pp. 367-374). Springer, Cham. https://doi.org /10.1007/978-3-030-16542-0 45.

9. Syomych, M. (2019). Features of modern models of public administration. Public Administration Aspects, 7(4), 44-52. https://doi. org/10.15421/151922.

10. El-Ghalayini, Y. (2016). New Public Management: An Assessment of Impact and the Influence on Public Administration. Public Policy and Administration Research, 6(12), 18-22.

11. Latysheva, O., Rovenska, V., Smyrnova, I., Nitsenko, V., Balezentis, T., \& Streimikiene, D. (2020). Management of the sustainable development of machine-building enterprises: a sustainable development space approach. Journal of Enterprise Information Management, 34(1), 328-342. https://doi.org/10.1108/JEIM-12-2019-0419.

12. Chand, A., \& Naidu, S. (2020). New Public Management Model and Performance Appraisal System. In Farazmand A. (Ed.) (2020). Global Encyclopedia of Public Administration, Public Policy, and Governance. Springer, Cham. https://doi.org/10.1007/978-3-319-31816-5 4031-1. 13. Mozgin, W. (2020). An Anthropocentric Perspective in Posthumanist and Transhumanist Discourse. Philosophy and Cosmology, 25, 108-117. https://doi.org/10.29202/phil-cosm/25/9.

14. Sokiran, M. (2020). Theoretical Approaches to the Definition of "Critical Space Infrastructure. Advanced Space Law, 6, 54-63. https:// doi.org/10.29202/asl/6/6.

15. Tang, W., \& Qiu, X. (2020). Construction of Law-based Government in the Context of Counteraction to COVID-19. Ukrainian Policymaker, 6, 74-84. https://doi.org/10.29202/up/6/8.

16. Lampropoulou, M., \& Oikonomou, G. (2018). Theoretical models of public administration and patterns of state reform in Greece. International Review of Administrative Sciences, 84(1), 101-121. https:// doi.org/10.1177/0020852315611219. 
17. Krukowski, K., \& Siemiński, M. (2018). New public management in organisations introducing agricultural policies in Poland. Management Theory and Studies for Rural Business and Infrastructure Development, 40(2), 206-215. https://doi.org/10.15544/mts.2018.20.

\section{Порівняльний аналіз моделей державного управління}

\section{К. Л. Інграм ${ }^{1}$, В. С. Ніценко}

1 - Вільнюський коледж, Університет прикладних наук, м. Вільнюс, Литовська Республіка, e-mail: k.ingram@vvf. viko.lt

2 - Фонд SCIRE, м. Варшава, Республіка Польща

Мета. Порівняльна оцінка відповідності існуючих парадигм, що ведуть до розробки нових моделей державного управління.

Методика. У дослідженні використано порівняльний аналіз для забезпечення всебічного розуміння із професійної та академічної точок зору існуючих моделей державного управління, що $є$ традиційним державним управлінням, новим державним управлінням, новим державним належним управлінням, просторові особливості, які сприяють новим парадигматичним «зразкам» та «точкам зору».

Результати. $E$ кілька важливих аспектів у розумінні парадигм у моделях державного управління. У певному сенсі загальні рамки моделей державного управління $€$ парадигмами, що постійно змінюються, коли настає криза. Це демонструє, що розроблені нові моделі державного управління не завжди вписуються в одну парадигму й можуть існувати в гібридному стані, коли різні характеристики одних парадигм перекривають іншу. Визначення цих характеристик допомагає встановити за- стосовність сучасних моделей до регулювання управління й керування суб'єктами та функціями державного сектору, а також їх призначення.

Наукова новизна. Попередні дослідження показують, шо були здійснені численні спроби зрозуміти й розробити системний підхід до порядку державного управління. На сьогоднішній день розвиток державного управління як дисципліни сприймається як послідовність парадигм, що перетинаються. Незважаючи на це, державне управління як і раніше залишається найважливішим аспектом бюрократії у світі. 3 урахуванням того, що уряд вирішуе всі аспекти громадянського суспільства в капіталістичних, соціалістичних і демократичних державах, цілі державного управління розглядаються як постійна зміна парадигми. Парадигми надають рішення й визначають, чи є області конкретного явища проблемними, і багато практикуючих державних адміністративних діячів часто мали парадигматичні припущення про те, що політики, посадові особи та громадяни керуються особистими інтересами та будуть сприймати розвиток державного управління у цьому ракурсі.

Практична значимість. Робота дає тлумачення функцій і перспектив державного управління як дисципліни, що веде до розвитку й переходу від традиційного державного управління (ТРА) до нового державного управління (NPM), потім до нового державного належного управління (NPG) і далі до інших пост-нових моделей державного управління.

Ключові слова: державне управління, традиційне державне управління, нове державне управління, нове державне належне управління, парадигма

Recommended for publication by N. Datsii, Doctor of Sciences in Public Administration. The manuscript was submitted 28.01.21. 